\title{
БЕЗСОННЯ ЯК ФАКТОР РИЗИКУ РОЗВИТКУ МОЗКОВОГО ІНСУЛЬТУ
}

\author{
${ }^{1}$ Тернопільський національний медичний університет \\ імені І. Я. Горбачевського МОЗ України, м. Тернопіль, Україна \\ ${ }^{2}$ Комунальне некомерційне підприємство «Тернопільська обласна клінічна психоневрологічна лікарня» \\ Тернопільської обласної ради, м. Тернопіль, Україна
}

\begin{abstract}
Мета: вивчити вплив порушень сну на розвиток мозкового інсульту.
Матеріали і методи. Проведено анкетування 98 пацієнтів із мозковим інсультом задля вивчення впливу порушень сну на розвиток мозкового інсульту в інсультному відділенні та у відділенні інтенсивної терапії та кризових станів Комунального некомерційного підприємства «Тернопільська обласна клінічна психоневрологічна лікарня» Тернопільської обласної ради. Стан порушень сну вивчено за допомогою пітсбурзького опитувальника якості сну (PSQI) та визначення індексу тяжкості безсоння (Insomnia Severity Index - ISI).

Результати. Встановлено, що у третини пацієнтів похилого віку $(34,4$ \%) нічний сон тривав менше 7 год, індекс тяжкості безсоння становив $(16,13 \pm 1,25)$ бала (помірні порушення сну), переважала частка помірних порушень сну (в $(43,75 \pm 1,04) \%)$ і відзначалася наявність виражених порушень сну (в $(18,75 \pm 1,66) \%)$. Пацієнти, старші 60 років, склали найбільшу групу з виявленим мозковим інсультом (65,3\%), при цьому гіпертонічну хворобу виявляли у них в 68,8 \% випадків, що свідчить про вплив порушення сну на розвиток артеріальної гіпертензії та мозкового інсульту.

Лікування порушень сну повинно стати складовою у профілактиці серцево-судинних захворювань, цереброваскулярної патології та мозкового інсульту. На думку провідних експертів для лікування порушень сну найкраще використовувати когнітивно-поведінкову терапію.

Висновки. Враховуючи доведений вплив порушень сну (інсомнії) на розвиток цереброваскулярних захворювань, необхідно впровадити в систему громадського здоров'я низку інформаційно-просвітницьких заходів для їх профрілактики та покращення рівня знань про психологічну освіту/гігієну сну. 3 метою виявлення та корекції неправильних переконань стосовно сну і хибних уявлень про безсоння та його наслідки забезпечити консультацію психолога або психотерапевта пацієнтам з гіпертонічною хворобою, особам, старшим 60 років, та всім пацієнтам, які скаржаться на порушення сну.
\end{abstract}

КЛЮчОВІ СЛОВА: мозковий інсульт; безсоння; фрактори ризику; індекс тяжкості безсоння.

На даний час скорочення тривалості нічного сну притаманне населенню більшості розвинутих країн світу. Згідно з останніми даними, понад $6 \%$ дорослого населення в індустріалізованих країнах потерпає від хронічного безсоння, до того ж із чітким переважанням серед чоловіків і осіб похилого віку, та простежується тенденція до зростання поширення безсоння у загальній популяції до 10 \%. У Європі на сьогодні поширеність інсомнії як захворювання коливається від 5,7 \% у Німеччині до $19 \%$ - у Франції. У Канаді майже в $70 \%$ пацієнтів протягом року спостерігають тривале збереження симптомів інсомнії. У $46 \%$ пацієнтів, які страждають від безсоння, фріксують персистенцію симптомів протягом трьох років. Приймання препаратів групи бензодіазепінів широко варіює в різних європейських країнах, що також підтверджує поширеність безсоння [3].

Такі ж дані про зменшення тривалості сну оприлюднив Національний фонд сну в США. Лише $37 \%$ американців сплять 8 год на добу, $31 \%$ опитаних - менше 6 год. На сьогодні статистичні дані свідчать про те, що люди сплять у середньому всього 6,8 год на добу, що на 1,5 год менше, ніж сто років тому [13].

На основі низки епідеміологічних досліджень доведено, що зменшення тривалості сну є неза-

(c) Н. О. Теренда, Н. Я. Фарійон, 2021 лежним фрактором ризику розвитку артеріальної гіпертензії (АГ), ішемічної хвороби серця (IXC) та цукрового діабету 2 типу (ЦД) [2, 12]. 3 позиції оцінки якості сну не можна не брати до уваги синдром обструктивного апное сну, роль якого ґрунтовно висвітлена щодо АГ [19], IXC [10] та ЦД [14]. D. L. Wingard та L. F. Berkman на основі проспективного аналізу ризику загальної смертності довели, що смертність від ішемічної хвороби серця, раку, інсульту та інших причин була найнижчою у когорті осіб, які спали 7-8 год на добу [18].

Збільшення кількості робочих годин призводить до зменшення годин сну. Y. Liu та співавт. встановили, що робота понад 60 год призводить до збільшення ризику захворюваності на гострий інсраркт міокарда у 2 рази порівняно 3 40-годинним робочим тижнем. Досліджувані, які відпочивали не більше 5 год на добу, мали в 2,3 раза більший ризик розвитку нефатального інфраркту міокарда порівняно 3 тими, хто отримував 6-8 год сну [11].

Поздовжні дослідження Sleep Heart Health Study (SHHS) Ta Massachusetts Male Aging Study (MMAS) довели, що в осіб, які відпочивали $\leq 5,6$ та >8 год на добу, було, відповідно, в два та в три рази більше шансів захворіти на ЦД порівняно 3 контрольною групою. При цьому варто зауважити, що ризики залишалися практично незмін- 
ними після врахування віку, наявності АГ, куріння, самооцінки стану здоров'я, рівня освіти та окружності талії. Таким чином, коротка або довга тривалість сну збільшує ризик розвитку ЦД незалежно від супутніх чинників. Це означає, що існує U-подібна залежність між тривалістю сну і захворюваністю на ЦД [2, 20].

Два основних когортних дослідження, Sleep Heart Health Study (SHHS) [5] i National Health and Nutrition Examination Survey (NHNES) [16], продемонстрували наявність зв'язку між короткою тривалістю сну і поширеністю артеріальної гіпертензії. Так, D. J. Gottlieb та співавт. [5] у дослідженні SHHS показали, що коротка і довга тривалість сну пов'язана з більш високою поширеністю артеріальної гіпертензії порівняно з такою в осіб, які спали 7-8 год на добу. Подібна тенденція відображена у Korean National Health and Nutrition survey 2001 [15].

Зв'язок між тривалістю сну та артеріальною гіпертензією залежав від віку і статі. Підлітки 3 коротшою тривалістю сну показали більш високу поширеність прегіпертензії [17]. 3 іншого боку, зв'язок між обмеженням сну і частотою розвитку АГ було виявлено в осіб віком 60-86 років у дослідженні NHNES [16]. У 1982 р. Національний інститут 3 проблем старіння (NIA) в результаті проведеного багатоцентрового епідеміологічного дослідження 3 метою оцінки поширеності скарг на розлади сну серед людей віком від 65 років і старше повідомив, що $57 \%$ обстежених мають деякі форми хронічного порушення сну: труднощі ініціації або підтримка сну (43\%), нічне неспання (30\%), безсоння (29\%), дрімота в денний час (25\%), проблеми із засинанням (19\%), ранні прокидання (19\%), відсутність відчуття відпочинку після сну. Інші дослідження, проведені у США, Китаї, Україні, вказують на порушення сну в осіб похилого віку в 15-25 \% випадків [6]. Зважаючи на коротку тривалість сну, артеріальна гіпертензія була більше поширена у жінок в Whitehall II Study [8].

Мета дослідження: вивчити вплив порушень сну на розвиток мозкового інсульту (MI).

Матеріали і методи. Проведено анкетування 98 пацієнтів із MІ задля вивчення впливу порушень сну на розвиток МІ в інсультному відділенні та у відділенні інтенсивної терапії та кризових станів Комунального некомерційного підприємства «Тернопільська обласна клінічна психоневрологічна лікарня» Тернопільської обласної ради (КНП «ТОКПНЛ» ТОР). Анкетування проводили шляхом безпосереднього опитування пацієнтів за заздалегідь складеною анкетою.

Стан порушень сну вивчали за допомогою пітсбурзького опитувальника якості сну (PSQI). На основі проведеного анкетування у пацієнтів з MI визначали тривалість нічного сну та індекс тяжкості безсоння (Insomnia Severity Index - ISI), які $€$ на даний час достатньо надійними і чутливими для встановлення в пацієнтів безсоння.

Результати дослідження та їх обговорення. Зважаючи на важливість сну для організму лю- дини та на виникнення певних захворювань при порушенні сну, ВООЗ оголосила 17 березня Всесвітнім днем сну.

Виникненню безсоння в осіб похилого віку сприяють різноманітні соматичні захворювання (порушення серцевого ритму, задишка внаслідок хронічної серцевої недостатності, напади бронхіальної астми, атеросклероз судин нижніх кінцівок, хвороба Паркінсона, больовий синдром внаслідок артриту, остеохондрозу, печія, стенокардія), психічні причини (депресія, короткочасні реакції на стрес, деменція), безконтрольне приймання медикаментозних середників (снодійних, сечогінних та ін.), поведінкові чинники (вживання кави, алкоголю, тютюнокуріння перед сном, компенсація нічного сну в денний час, низька фрізична активність).

У осіб, старших 65 років, частіше буває занадто короткий (4-5 год) або занадто тривалий (9-10 год) сон. До 75 \% смертей у цьому віці пов'язують з занадто тривалим/коротким сном. Внаслідок недосипання прискорюється процес відкладання кальцію в коронарних артеріях, посилюється активація гіпоталамо-гіпофрізарнонаднирковозалозної системи і підвищується тонус симпатичної нервової системи. Недосипання негативно впливає на гіпоталамус, зумовлюючи збільшення апетиту, що призводить до надмірного споживання їжі та до надлишкової маси тіла. Позбавлення сну також пов'язано 3 системним запаленням, оксидантним стресом i ендотеліальною дисфункцією - всіма фракторами ризику розвитку артеріальної гіпертензії [1, 9]. Недосипання також додатково спонукає до розвитку довготривалого психосоціального стресу, який призводить до збільшення споживання солі та гальмування екскреції натрію нирками [7]. Ці процеси можуть бути додатковими чинниками розвитку артеріальної гіпертензії шляхом перевантаження об'ємом та структурно-функціональною перебудовою артеріальних судин. Наведені результати недосипання - одні 3 основних фракторів розвитку серцево-судинної патології (артеріальна гіпертензія, ішемічна хвороба серця, серцеві аритмії). Все це в сукупності збільшує ризик загальної смертності в похилому віці на $48 \%$ і на 15 \% збільшує ризик MІ, в тому числі 3 летальними наслідками [4].

Серед опитаних пацієнтів з МІ чоловіків було 64 (65,3\%), жінок - 34 (34,7\%). Вік пацієнтів коливався від 26 до 86 років, склавши в середньому $(63,86 \pm 2,12)$ року. Серед опитаних пацієнтів 14 (14,3 \%) були молодого віку, 20 (20,4 \%) - середнього віку та 64 (65,3 \%) - особи похилого віку (згідно з класифікацією ВООЗ).

Серед анкетованих переважали особи пенсійного віку (57,1 \%). Фізичною працею (робітники) займалися 10,2 \% анкетованих, розумовою 4,1\%, тимчасово не працювали - 28,6\%.

Отримані дані свідчать про вплив біологічних фракторів: статі (переважання чоловіків), віку (57,1\% осіб пенсійного віку); соціально-економічних: безробіття $(28,6 \%)$ на розвиток MI. 
Однією з провідних причин розвитку MI є apтеріальна гіпертензія. Гіпертонічна хвороба діагностована в 66 (67,3 \%) пацієнтів 3 MІ. Щоденний контроль артеріального тиску здійснювали лише 10 (10,2 \%) опитаним, 1-2 рази на тиждень вимірювали артеріальний тиск 18 (18,4 \%) респондентам, при потребі - 46 (46,9 \%), ніколи не контролювали артеріальний тиск і виявили його при $\mathrm{MI}$ - у 24 (24,5 \%) хворих.

При цьому рекомендовані лікарями препарати гіпотензивної дії приймали регулярно лише 10 (10,2 \%) респондентів, 1-2 рази на тиждень 18 (18,4 \%), іноді при потребі - 52 (53,1 \%). Ніколи не використовували гіпотензивну терапію, рекомендовану сімейним лікарем або кардіологом, $18(18,4 \%)$ опитаних.

Тютюнокуріння як поведінковий фрактор ризику розвитку МІ виявлено у 44 (44,9 \%) пацієнтів 3

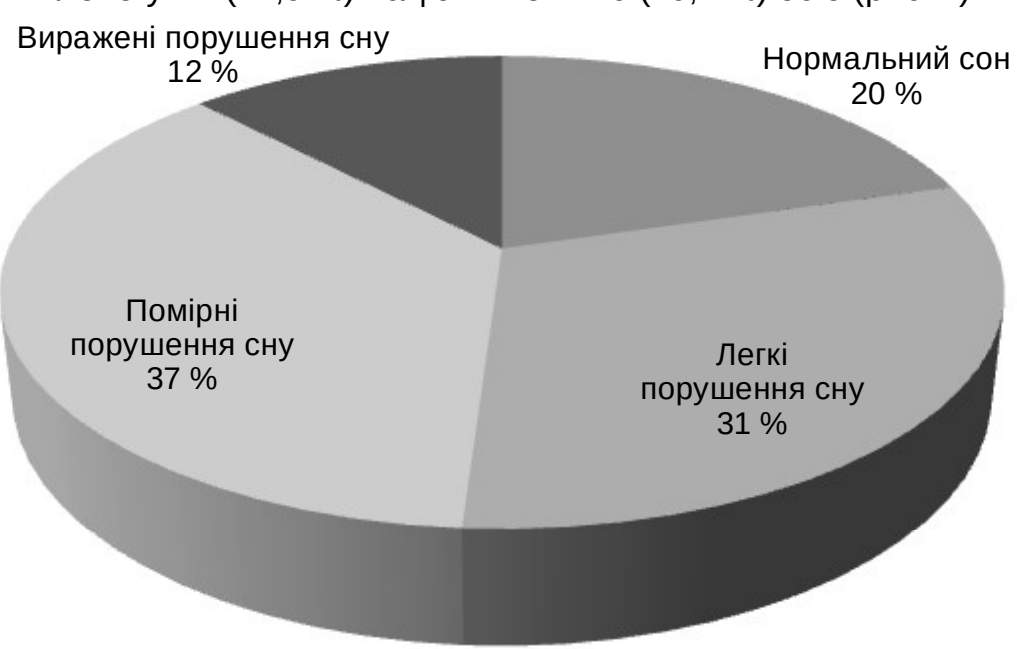

Puc. 1. Структура індексу тяжкості безсоння у пацієнтів із мозковим інсультом.

Більшість чоловіків (68,8 \%) спала 7-8 год на добу, менше 7 год спали 18,8\%, більше 8 год $12,4 \%$. Серед них переважала група з легкими порушеннями сну $((37,50 \pm 1,29) \%)$, майже чверть

опитаних мала помірні порушення сну і виражені порушення сну спостерігали в $(15,63 \pm 1,13) \%$ (табл. 1).

Таблиця 1. Структура індексу тяжкості безсоння у пацієнтів із мозковим інсультом залежно від статі (абс., \% $\pm m$ )

\begin{tabular}{|l|c|c|c|c|c|}
\hline \multirow{2}{*}{ Соціальний статус } & \multicolumn{2}{|c|}{$\begin{array}{c}\text { Чоловіки } \\
(\mathrm{n}=64)\end{array}$} & \multicolumn{2}{c|}{$\begin{array}{c}\text { Жінки } \\
(\mathrm{n}=34)\end{array}$} \\
\cline { 2 - 5 } & абс. & $\%$ & абс. & $\%$ & \\
\hline Нормальний сон & 14 & $21,88 \pm 1,11$ & 3 & $17,65 \pm 1,22$ & 0,1151 \\
\hline Легкі порушення сну & 24 & $37,50 \pm 1,29$ & 3 & $17,65 \pm 1,22$ & 0,0661 \\
\hline Помірні порушення сну & 16 & $25,00 \pm 1,34$ & 20 & $58,82 \pm 1,08$ & 0,0364 \\
\hline Виражені порушення сну & 10 & $15,63 \pm 1,13$ & 2 & $5,88 \pm 1,50$ & 0,0605 \\
\hline
\end{tabular}

Жінки переважно також спали по 7-8 год на добу (64,7 \%), менше 7 год спали 29,4 \%, більше 8 год - 5,9\%. У жінок спостерігали тенденцію до вищого рівня індексу тяжкості безсоння $((14,41 \pm 1,29)$ бала) порівняно з чоловіками $((13,63 \pm 1,03)$ бала). Також у них достовірно переважали помірні порушення сну $(p=0,0364)$. Більшість жінок $((58,82 \pm 1,08) \%)$ мала помірні порушення сну.

Нормальний сон спостерігали в $(21,88 \pm 1,11) \%$ чоловіків та $(17,65 \pm 1,22) \%$ жінок.

MI, 54 (55,1 \%) - не курять. Істотне значення має кількість отриманого нікотину та продуктів горіння цигарок. Так, до 10 цигарок на добу викурюють $36(81,8 \%)$ від усіх курців, більше 10 цигарок $8(18,2 \%)$.

Нервове перенавантаження, стрес на роботі або вдома відчувають постійно 2 (2,0 \%) особи, часто - 22 (22,4 \%), іноді - 66 (67,3\%), ніколи не .

На тривалість нічного сну в межах 7-8 год вказувало 51,0 \% пацієнтів $3 \mathrm{Ml}$, менше 7 год спали $38,8 \%$ опитаних, більше 8 год - 10,2 \%. Індекс

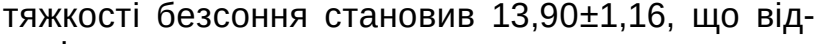
відає легкому ступеню порушення сну.

У пацієнтів з MI переважали помірні порушення сну в 36 (36,7\%), легкі - у 30 (30,6 \%), виражені - в 12 (12,2\%), нормальний сон був лише у $20(20,4 \%)$ осіб (рис. 1). 
Таблиця 2. Структура індексу тяжкості безсоння у пацієнтів із мозковим інсультом у різних вікових групах (абс., \% $\pm \mathrm{m})$

\begin{tabular}{|c|c|c|c|c|c|c|c|c|c|}
\hline \multirow{3}{*}{ Індекс тяжкості безсоння } & \multicolumn{6}{|c|}{ Вік } & \multirow{3}{*}{$p_{1-2}$} & \multirow{3}{*}{$p_{1-3}$} & \multirow{3}{*}{$p_{2-3}$} \\
\hline & \multicolumn{2}{|c|}{$\begin{array}{c}\text { до } 44 \text { роки } \\
(\mathrm{n}=14)\end{array}$} & \multicolumn{2}{|c|}{$\begin{array}{c}\text { 45-59 років } \\
(n=20)\end{array}$} & \multicolumn{2}{|c|}{$\begin{array}{c}\text { старше } 60 \text { років } \\
(n=64)\end{array}$} & & & \\
\hline & абс. & $\%$ & абс. & $\%$ & абс. & $\%$ & & & \\
\hline Нормальний сон & 12 & $85,71 \pm 1,37$ & 6 & $30,00 \pm 1,02$ & 2 & $3,13 \pm 1,25$ & 0,0451 & 0,0073 & 0,0596 \\
\hline Легкі порушення сну & - & - & 8 & $40,00 \pm 2,19$ & 22 & $34,38 \pm 1,56$ & 0,000 & 0,000 & 0,1578 \\
\hline Помірні порушення сну & 2 & $14,29 \pm 1,93$ & 6 & $30,00 \pm 1,02$ & 28 & $43,75 \pm 1,04$ & 0,0862 & 0,0659 & 0,1245 \\
\hline Виражені порушення сну & - & - & - & - & 12 & $18,75 \pm 1,66$ & - & 0,000 & 0,000 \\
\hline
\end{tabular}

соння у них становив $(11,80 \pm 1,87)$ бала, що відповідає рівню легких порушень сну. Помірні порушення сну та нормальний сон у них - по 30,0\%.

У віковій групі старше 60 років 7-8 год спала менша частина обстежених, порівняно 3 групою 45-59 років - 59,4 \%, менше 7 год нічний сон тривав у 34,4 \% і більше 8 год - у 6,3\%. Індекс тяжкості безсоння у цій групі становив $(16,13 \pm 1,25)$ бала, що відповідає рівню помірних порушень сну. Також у цій групі переважала частка помірних порушень сну $((43,75 \pm 1,04)$ бала) та відзначалася наявність виражених порушень сну $((18,75 \pm 1,66)$ бала).

Отже, отримані дані свідчать про те, що пацієнти молодого віку (57,1 \%) найчастіше спали менше 7 год на добу порівняно із особами середнього (10,0 \%) та похилого віку (34,4 \%). Проте індекс тяжкості безсоння у них становив $(6,71 \pm 2,03)$ бала і зростав у кожній наступній віковій групі $((11,80 \pm 1,87)$ бала та $(16,13 \pm 1,25)$ бала відповідно). Також спостерігали достовірне переважання нормального сну в групі пацієнтів із МІ віком до 44 роки порівняно із групами віком 4559 років та старше 60 років $(p=0,0451$ та $p=0,0073$ відповідно). У даній ситуації спрацьовують компенсаторні механізми організму (серцево-судинна і нейрорегуляторна функції).

У пацієнтів середнього віку з MI спостерігали найчастіше легкі порушення сну (індекс тяжкості безсоння - $(11,80 \pm 1,87)$ бала). У третини пацієнтів похилого віку $(34,4 \%)$ нічний сон тривав менше 7 год, індекс тяжкості безсоння становив $(16,13 \pm 1,25)$ бала (помірні порушення сну) та переважала частка помірних порушень сну (в $(43,75 \pm 1,04) \%)$ і відзначалася наявність виражених порушень сну (в $(18,75 \pm 1,66) \%)$. Пацієнти, старші 60 років, склали найбільшу групу 3 виявленим MI (65,3 \%), при цьому гіпертонічну хворобу виявляли у них в 68,8 \% випадків, що свідчить про опосередкований вплив порушення сну на розвиток артеріальної гіпертензії та МI.

Враховуючи наведені фракти, лікування порушень сну повинно стати складовою у профілактиці серцево-судинних захворювань, церебро- васкулярної патології та мозкового інсульту. Первинними цілями лікування розладів сну є поліпшення якості та кількості сну зі зменшенням денних наслідків порушень нічного сну.

Для лікування безсоння в похилому віці використовують психологічні стратегії, фрармакологічні препарати або їх поєднання. Психологічні методи варто розглядати як початкові методи лікування завдяки переконливим емпіричним даним клінічних досліджень, високому рівню безпеки в осіб похилого віку, низьким матеріальним затратам, а також довгостроковій вигоді.

На думку провідних експертів для лікування порушень сну найкраще використовувати когнітивно-поведінкову терапію. Вона включає методики обмеження сну і контроль подразників, а також рекомендації щодо гігієни сну й фрізичної активності, навчання пацієнта технікам релаксації та роботи 3 негативними думками. На даний час психологічні втручання 3 приводу безсоння охоплюють безліч різних методів, включаючи психоосвіту щодо сну, когнітивну терапію, гігієну сну, стратегії релаксації, контроль стимулів, обмеження сну, а також багатокомпонентне лікування.

Висновки
Враховуючи доведений вплив порушень сну (інсомнії) на розвиток цереброваскулярних захворювань, необхідно впровадити в систему громадського здоров'я низку інорормаційнопросвітницьких заходів для їх профілактики та покращення рівня знань про психологічну освіту/ гігієну сну. Рекомендуємо з метою виявлення та корекції неправильних переконань стосовно сну і хибних уявлень про безсоння та його наслідки забезпечити консультацію психолога або психотерапевта пацієнтам із гіпертонічною хворобою, особам, старшим 60 років, та всім пацієнтам, які скаржаться на порушення сну.

Перспективи подальших досліджень полягають у вивченні стану здоров'я пацієнтів, яким проводили когнітивно-поведінкову терапію для лікування порушень сну.

\section{Список літератури}

1. Артериальная гипертензия и сон. Информационное письмо европейского общества гипертензии / Jean-Louis Pépin, Anne-Laure Borel, Jean-Phillipe Baguet et al. // Артериальная гипертензия. - 2010. - T. 46, № 5 (13). - C. $56-59$. 2. Візір В. А. Тривалість сну як фактор ризику серцево-судинних захворювань [Електронний ресурс] / В. А. Візір, А. С. Садомов, О. В. Деміденко // Артериальная гипертензия. - 2013. - № 1 (27). - Режим доступу : http://www.mif-ua. com/archive/issue-34128/. 
3. Європейські настанови з діагностики та лікування безсоння // НейроNEWS: психоневрологія та нейропсихіатрія. 2018. - № 1. - C. 46-53.

4. Хаустова О. О. Розлади сну у осіб літнього віку [Електронний ресурс] / О. О. Хаустова // HейроNEWS: психоневрологія та нейропсихіатрія. - 2016. - № 1-2. - Режим доступу : https://neuronews.com.ua/ua/archive/2016/2-1/ article-1660/rozladi-snu-u-osib-litnogo-viku\#gsc.tab=0.

5. Association of usual sleep duration with hypertension: the Sleep Heart Health Study / D. J. Gottlieb, S. Redline, F. J. Nieto [et al.] // Sleep. - 2006. - Vol. 29. - P. 1009-1014.

6. European Stroke Organisation (ESO) guidelines for the management of spontaneous intracerebral hemorrhage I T. Steiner, R. Al-Shahi Salman, R. Beer [et al.] // Int. J. Stroke. - 2014. - Vol. 9. - P. 840-855.

7. Folkow B. Mental stress and its importance for cardiovascular disorders; physiological aspects, «from mice to man» / B. Folkow // Scand. Cardiovasc. J. - 2001. - Vol. 35. - P. 163-172.

8. Gender-specific associations of short sleep duration with prevalent and incident hypertension: the Whitehall II Study I F. P. Cappuccio, S. Stranges, N. B. Kandala [et al.] // Hypertension. - 2007. - Vol. 50. - P. 693-700.

9. Increased sympathetic and decreased parasympathetic cardiovascular modulation in normal humans with acute sleep deprivation / X. Zhong, H. J. Hilton, G. J. Gates [et al.] // J. Appl. Physiol. - 2005. - Vol. 98. - P. 2024-2032.

10. Leung R. S. Sleep apnea and cardiovascular disease / R. S. Leung, T. D. Bradley // Am. J. Respir. Crit. Care Med. 2001. - Vol. 164. - P. 2147-2165.

11. Liu Y. The Fukuoka Heart Study Group. Overtime work, insufficient sleep, and risk of nonfatal acute myocardial infarction in Japanese men / Y. Liu, H. Tanaka // Occup. Environ. Med. - 2002. - Vol. 59. - P. 447-451.

12. Nagai M. Sleep disorder and hypertension / M. Nagai, K. Kario // Nihon Rinsho. - 2012. - Vol. 70 (7). - P. $1188-1194$.

13. National Sleep Foundation. Sleep in America Poll 2003. - Washington, DC: National Sleep Foundation, 2003.

14. Punjabi N. M. Disorders of glucose metabolism in sleep apnea / N. M. Punjabi, V. Y. Polotsky // J. Appl. Physiol. 2005. - Vol. 99. - P. 1998-2007.

15. Relationship between sleep duration and the metabolic syndrome: Korean National Health and Nutrition Survey $2001 /$ K. M. Choi, J. S. Lee, H. S. Park [et al.] // Int. J. Obes. (Lond). - 2008. - Vol. 32. - P. 1091-1097.

16. Short sleep duration as a risk factor for hypertension: analyses of the first National Health and Nutrition Examination Survey / J. E. Gangwisch, S. B. Heymsfield, B. Boden-Albala [et al.] // Hypertension. - 2006. - Vol. 47. - P. 833-839.

17. Sleep quality and elevated blood pressure in adolescents / S. Javaheri, A. Storfer-Isser, C. L. Rosen, S. Redline // Circulation. - 2008. - Vol. 118. - P. 1034-1040.

18. Wingard D. L. Mortality risk associated sleeping patterns among adults / D. L. Wingard, L. F. Berkman // Sleep. 1983. - Vol. 6. - P. 102-107.

19. Wolk R. Obesity, sleep apnea, and hypertension / R. Wolk, A. S. Shamsuzzaman, V. K. Somers // Hypertension. 2003. - Vol. 42. - P. 1067-1074.

20. Yaggi H. K. Sleep duration as a risk factor for the development of type 2 diabetes / H. K. Yaggi, A. B. Araujo, J. B. McKinlay // Diabetes Care. - 2006. - Vol 29. - P. 657-661.

\section{References}

1. Pépin, Jean-Louis., Borel, Anne-Laure., Baguet, Jean-Phillipe., Tamisier, Renaud., Lévy, Patrick., \& Mallion, JeanMichel (2010). Arterialnaya gipertenziya i son. Informatsionnoye pismo yevropeyskogo obshchestva gipertenzii [Arterial hypertension and sleep. European Society of Hypertension Information Letter]. Arterialnaya gipertenziya - Arterial Hypertension, 46, 5(13), 56-59 [in Russian].

2. Vizir, V.A., Sadomov, A.S., \& Demidenko, O.V. (2013). Tryvalist snu yak faktor ryzyku sertsevo-sudynnykh zakhvoryuvan [Sleep duration as a risk factor for cardiovascular diseases]. Arteryalnaya hypertenzyya - Arterial Hypertension, 1 (27) Retrieved from http://www.mif-ua.com/archive/issue-34128/ [in Ukrainian].

3. (2018). Yevropeyski nastanovy z diahnostyky ta likuvannya bezsonnya [European guidelines for the diagnosis and treatment of insomnia]. NeyroNEWS: psykhonevrolohiya ta neyropsykhiatriya - NeuroNEWS: psychoneurology and neuropsychiatry, 1, 46-53 [in Ukrainian].

4. Khaustova, O.O. (2016). Rozlady snu u osib litnoho viku [Sleep disorders in the elderly]. NeyroNEWS: psykhonevrolohiya ta neyropsykhiatriya - NeuroNEWS: Psychoneurology and Neuropsychiatry, 1-2. Retrieved from https://neuronews.com. ua/ua/archive/2016/2-1/article-1660/rozladi-snu-u-osib-litnogo-viku\#gsc.tab=0 [in Ukrainian].

5. Gottlieb, D.J., Redline, S., Nieto, F.J., Baldwin, C.M., Newman, A.B., \& Resnick, H.E. (2006). Association of usual sleep duration with hypertension: the Sleep Heart Health Study. Sleep, 29, 1009-1014.

6. Steiner, T., Al-Shahi Salman R., Beer, R., Christensen, H., Cordonnier, Ch., \& Csiba, L. (2014). European Stroke Organisation (ESO) guidelines for the management of spontaneous intracerebral hemorrhage. Int. J. Stroke, 9, 840-855.

7. Folkow, B. (2001). Mental stress and its importance for cardiovascular disorders; physiological aspects, «from mice to man». Scand. Cardiovasc. J., 35, 163-172.

8. Cappuccio, F.P., Stranges, S., Kandala, N.B., Miller M.A., Taggart, F.M., \& Kumari, M. (2007). Gender-specific associations of short sleep duration with prevalent and incident hypertension: the Whitehall II Study. Hypertension, 50, 693-700.

9. X. Zhong, H.J. Hilton, G.J. Gates Jelic, S., Stern, Y., \& Bartels, M.N. (2005). Increased sympathetic and decreased parasympathetic cardiovascular modulation in normal humans with acute sleep deprivation. J. Appl. Physiol., 98, 20242032.

10. Leung, R.S., \& Bradley, T.D. (2001). Sleep apnea and cardiovascular disease. Am. J. Respir. Crit. Care Med., 164, 2147-2165. 
11. Liu, Y., \& Tanaka, H. (2002). The Fukuoka Heart Study Group. Overtime work, insufficient sleep, and risk of nonfatal acute myocardial infarction in Japanese men. Occup. Environ. Med., 59, 447-451.

12. Nagai, M. \& Kario, K. (2012). Sleep disorder and hypertension. Nihon Rinsho, 70(7), 1188-1194.

13. (2003). National Sleep Foundation. Sleep in America Poll 2003. Washington, DC: National Sleep Foundation.

14. Punjabi, N.M., \& Polotsky, V.Y. (2005). Disorders of glucose metabolism in sleep apnea. J. Appl. Physiol., 99, 19982007.

15. Choi, K.M., Lee, J.S., Park, H.S., Baik, S.H., Choi, D.S., \& Kim, S.M. (2008). Relationship between sleep duration and the metabolic syndrome: Korean National Health and Nutrition Survey 2001. Int. J. Obes. (Lond)., 32, 1091-1097.

16. Gangwisch, J.E., Heymsfield, S.B., Boden-Albala, B., Buijs, R.M., Kreier, F., \& Pickering, T.G. (2006). Short sleep duration as a risk factor for hypertension: analyses of the first National Health and Nutrition Examination Survey. Hypertension, 47, 833-839.

17. Javaheri, S., Storfer-Isser, A., Rosen, C.L., \& Redline, S. (2008). Sleep quality and elevated blood pressure in adolescents. Circulation, 118, 1034-1040.

18. Wingard, D.L. \& Berkman, L.F. (1983). Mortality risk associated sleeping patterns among adults. Sleep, 6, $102-107$.

19. Wolk, R., Shamsuzzaman, A.S., \& Somers, V.K. (2003). Obesity, sleep apnea, and hypertension. Hypertension, 42, 1067-1074.

20. Yaggi, H.K., Araujo, A.B., \& McKinlay, J.B. (2006). Sleep duration as a risk factor for the development of type 2 diabetes. Diabetes Care, 29, 657-661.

INSOMNIA AS A RISK FACTOR OF STROKE DEVELOPMENT

N. O. Terenda ${ }^{1}$, N. Ya. Fariyon ${ }^{2}$

${ }^{1}$ I. Horbachevsky Ternopil National Medical University, Ternopil, Ukraine

${ }^{2}$ Municipal non-profit enterprise «Ternopil Regional Clinical Psychoneurological Hospital» of Ternopil Regional Council, Ternopil, Ukraine

Purpose: to study the effect of sleep disorders on the development of stroke (MI).

Materials and Methods. A survey of 98 patients with MI to study the impact of sleep disorders on the development of $\mathrm{MI}$ in the stroke department and in the intensive care unit and crisis conditions of the Municipal Non-Profit Enterprise «Ternopil Regional Clinical Psychoneurological Hospital» Ternopil Regional Council (KNP «TOKPNL» TOR). The state of sleep disorders was studied using the Pittsburgh Sleep Quality Questionnaire (PSQI) and the Insomnia Severity Index (ISI).

Results. It was found that in one third of elderly patients (34.4\%) night sleep lasted less than 7 hours, the index of insomnia severity was $16.13 \pm 1.25$ points (moderate sleep disorders) and the proportion of moderate sleep disorders prevailed $(43.75 \pm 1.04 \%)$ and the presence of severe sleep disorders $(18.75 \pm 1.66 \%)$ was noted. Patients older than 60 years were the largest group with detected MI (65.3\%), while hypertension was detected in them in $68.8 \%$ of cases, which indicates the impact of sleep disorders on the development of hypertension and MI.

Treatment of sleep disorders should be part of the prevention of cardiovascular disease, cerebrovascular disease and stroke. According to leading experts, it is best to use cognitive-behavioral therapy to treat sleep disorders.

Conclusions. Given the proven impact of sleep disorders (insomnia) on the development of cerebrovascular diseases, it is necessary to introduce a number of informational and educational measures in the public health system in order to prevent them and improve the level of knowledge about psychological education / sleep hygiene. In order to identify and correct misconceptions about sleep and misconceptions about insomnia and its consequences, consult a psychologist or psychotherapist for patients with hypertension, people over 60 years and all patients who complain of sleep disorders.

KEY WORDS: stroke; insomnia; risk factors; insomnia severity index.

Рукопис надійшов до редакції 20.04.2021 p.

\section{Відомості про авторів:}

Теренда Наталія Олександрівна - доктор медичних наук, професор кафедри громадського здоров'я та управління охороною здоров'я Тернопільського національного медичного університету імені І. Я. Горбачевського МО3 України; тел.: +38(0352)-52-72-33.

Фарійон Надія Ярославівна - заступник генерального директора Комунального некомерційного підприємства «Тернопільська обласна клінічна психоневрологічна лікарня» Тернопільської обласної ради; тел.: +38(0352)-43-57-28. 